\title{
Synthesis, antibacterial activity and cytotoxicity of new fused pyrazolo[1,5-a]pyrimidine and pyrazolo[5,1-c] $[1,2,4]$ triazine derivatives from new 5-aminopyrazoles
}

\begin{abstract}
New 5-aminopyrazoles $2 \mathrm{a}-\mathrm{c}$ were prepared in high yields from the reaction of known $\alpha, \alpha-$ dicyanoketene-N,S-acetals $1 \mathrm{a}-\mathrm{c}$ with hydrazine hydrate under reflux in ethanol. These compounds were utilized as intermediates to synthesize pyrazolo[1,5-a]-pyrimidines $3 \mathrm{a}-\mathrm{c}$, $4 \mathrm{a}-\mathrm{d}, 5 \mathrm{a}-\mathrm{c}$, and $6 \mathrm{a}-\mathrm{c}$, as well as pyrazolo[5,1-c][1,2,4]triazines $7 \mathrm{a}-\mathrm{c}$ and $8 \mathrm{a}-\mathrm{c}$, by the reaction of 2-[bis(methylthio)methylene]malononitrile, $\alpha, \alpha$-dicyanoketene-N,S-acetals $1 \mathrm{a}-\mathrm{b}$, acetylacetone, acetoacetanilide as well as acetylacetone, and malononitrile, respectively. Furthermore, cyclization of $2 \mathrm{a}-\mathrm{c}$ with pentan-2,5-dione yielded the corresponding 5pyrrolylpyrazoles $9 \mathrm{a}-\mathrm{c}$. Moreover, fusion of $2 \mathrm{a}-\mathrm{c}$ with acetic anhydride resulted in the corresponding 1-acetyl-1H-pyrazoles $10 \mathrm{a}-\mathrm{c}$. The antibacterial activity and cytotoxicity against Vero cells of several selected compounds are also reported.
\end{abstract}

Keyword: 5-Aminopyrazoles; Pyrazolo[1,5-a]pyrimidines; Pyrazolo[5,1-c][1,2,4]triazines; $\alpha, \alpha$-Dicyanoketene-S,S- and N,S-acetals; Antibacterial activity; Cytotoxicity. 